\title{
Effectiveness Of Rosella Tea On Decreasing Blood Pressure In Hypertension Patients In Tulungagung District
}

\author{
Farida*, Yusuf Abdillah, Poppy Farasari \\ STIKes Hutama Abdi Husada Tulungagung, East Java, Indonesia \\ poprimf@gmail.com
}

\begin{abstract}
Blood pressure becomes pathological, and can be said to be problematic if in a high point $(\geq$ $140 / 90)$ and in low point $(\leq 90 / 60)$ that is persistent. Blood pressure at a high level or point is called hypertension. In Southeast Asia the prevalence of hypertension reaches $33 \%$ with a mortality rate of 1.5 million. Rosella contains $33.9 \%$ soluble compounds that help shed fat. Rosella also contains anthocyanins, the antioxidant flavonoid that can reduce blood pressure by preventing atherosclerosis (clogged arteries) by oxidizing lipids/LDL.The aim of the study was to determine the effectiveness of rosella tea to decrease blood pressure in hypertensive patients in Tulungagung Regency.

The research design used pre experimental. The sampling technique uses quota sampling with a sample of 30 respondents. Samples were taken from some hypertensive patients in Blimbing village, Rejotangan sub-district, Tulungagung district. Design research was one group pretest-posttest. The study used a dose of $2 \times 3$ grams of dried rosella each day for seven (7) days. Test Statistics using Paired T test.

The results of the study were obtained before the treatment as many as 26 respondents $(86.7 \%)$ with the classification of stage 1 hypertension and after treatment to 18 respondents $(60 \%)$, this was due to filling vacancies in the incidence of prehypertension and normal tension.normality test Kolmogorov-smirnof data is normally distributed. The results of thestatistical Paired T-testtest showed that the value of $\mathrm{p}$ systole $=0,000$ and dyastole $=$ 0.001 with $\alpha=0.05$ where $\mathrm{p}<\alpha$ so that Ho was rejected, which means there was a decrease in the average blood pressure after giving rosella tea.

It was concluded that administration of rosella tea for seven (7) consecutive days was effective to reduce blood pressure so that it could be used as an alternative choice to replace pharmacological management of hypertension.
\end{abstract}

Keywords: Blood Pressure, Rosella Tea, Hypertension. 


\section{STRADA Jurnal Ilmiah Kesehatan}

DOI: $10.30994 /$ sjik.v9i1.277

ISSN: 2252-3847 (print); 2614-350X (online)

Vol.9 No.1. May 2020. Page.162-169

\section{BACKGROUND}

Blood pressure is the force of pushing blood to the arterial wall that comes from the contraction activity of the heart muscle. Every day our blood pressure naturally goes dynamic. A person's lifestyle also affects the rise and fall of blood pressure. Pressing blood becomes pathological, and can be said to be problematic if it is in a high point $(\geq 140 / 90)$ and a low point $(\leq 90 / 60)$ that is persistent. Blood pressure at a high level or point is called hypertension (Anna Palmer, 2007).

Data from the World Health Organization (WHO) in 2011 showed that one billion people in the world suffer from hypertension, $66 \%$ of whom are in developing countries with low to moderate income. The prevalence of hypertension will continue to rise sharply and it is predicted that by 2025 as many as $29 \%$ of adults worldwide will develop hypertension. Hypertension has resulted in the deaths of around 8 million people each year, a total of 1.5 million deaths in Southeast Asia with a prevalence of hypertension of $33 \%$ of the population.

Many factors that cause hypertension, one of the factors causing hypertension is age. The results of the 2013 Riskesdas showed that the highest age group of hypertensive patients was the productive age group (35-54 years old) whereas in the elderly (55-54 years old) hypertension was at risk for stroke $(12.3 \%)$. Consumption of high-fat foods is also one of the risk factors for hypertension in addition to increased behavior and unhealthy lifestyles, such as: tobacco consumption will increase the risk of hypertension. Another factor is genetics, that is, parents who carry high blood pressure are likely to reduce high blood pressure in their children.

Hypertension is also called the "silent killer" because this disease does not cause long-term symptoms but may lead to life-threatening complications. A high blood pressure makes the circulatory system and other organs that get blood supply tense. If blood pressure is not controlled properly, it can cause a variety of serious problems for other organs, namely: heart (angina pectoris, decompensation cordis, heart attack), nerves ( stroke), kidney (kidney failure), eyes (glaucoma). Besides high blood pressure persistent can also cause peripheral circulatorydisease claudication, aneurysmaortic, and brain disorders such as dementia. (Anna Palmer, 2007).

Everyone is at risk of developing high blood pressure, so that from now we have to plan the right treatment to control blood pressure. In controlling blood pressure there are several alternative solutions, one of which is the consumption of substances that can dissolve cholesterol, and contain antioxidants, namely rosella flower tea. Rosella contains $33.9 \%$ soluble compounds that help shed fat. Rosella flowers also contain anti-oxidants, Anthocyanins which are anti-oxidants in the flavonoid group. Anthocyanins can reduce blood pressure by preventing the occurrence of atherosclerosis (blockage of blood vessels) by oxidizing bad / LDL fats. In Indonesia there is a habit of serving tea drinks at leisure and for guests. It would be better if the drinks served are powerful herbal drinks such as Rosella flower tea which is efficacious for various diseases, especially as an alternative to hypertension (Rahmawati Reni, 2012).

Based on the background above, the researchers were interested in conducting a study of "Effectiveness of Rosella Tea on Decreasing Blood Pressure in Hypertension Patients in Tulungagung District"

The hypothesis of this study is that there is an effect of giving rosella tea to a decrease in systolic and diastolic blood pressure between before and after intervention in the community of Blimbing village, Kec. Rejotangan, Tulungagung Regency. 


\section{STRADA Jurnal Ilmiah Kesehatan}

DOI: $10.30994 /$ sjik.v9i1.277

\section{METHOD}

Research design Pre Experimental, is a study without involving the control group. This study uses the design of One Group Pretest-Posttest Design. In this design observations were made twice, namely before the experiment and after the experiment (Arikunto, 2010).

Population is All Hypertension Patients in Tulungagung Regency.

The sample in this study is the Most Patients with Hypertension as many as 30 people in the village of Blimbing, District Rejotangan, Tulungagung, who meet the inclusion and exclusion criteria, data collection using observation of blood pressure before and after treatment, and the research was conducted on 17-23 June 2018.

Analysis of the influence Rosella tea to reduce blood pressure starts with a normality test first, followed by a statistical test paired t-test,if $p$ value $<\alpha(0.05)$ is said to be significant, then the null hypothesis (Ho) is rejected, meaning rosella tea is effective against decline blood pressure in people with hypertension.

\section{RESULT}

a. Respondents' blood pressure before treatment.

Table 1 Systolic Blood Pressure Before Treatment

\begin{tabular}{llll}
\hline & Mean & N & $\begin{array}{l}\text { Std. } \\
\text { Deviasi }\end{array}$ \\
\hline Sistole & 145.33 & 30 & 7.303 \\
\hline
\end{tabular}

Table 1 shows that the mean (mean) of systole blood pressure before being given rosela tea is $145.33 \mathrm{mmHg}$

Table 2 Diastolic Blood Pressure Before Treatment

\begin{tabular}{llll}
\hline & Mean & $\mathrm{N}$ & $\begin{array}{l}\text { Std. } \\
\text { Deviasi }\end{array}$ \\
\hline Dyastole & 91.33 & 30 & 3.457 \\
\hline
\end{tabular}

Table 2 shows that the mean (mean) of diastolic blood pressure before being given rosela tea is $91.33 \mathrm{mmHg}$

b. Respondents' blood pressure after treatment

Table 3 Systole Blood Pressure after Treatment

\begin{tabular}{llll}
\hline & Mean & N & $\begin{array}{l}\text { Std. } \\
\text { Deviasi }\end{array}$ \\
\hline Sistole & 139.67 & 30 & 9.279 \\
\hline
\end{tabular}

Table 3 shows that the mean (mean) of siatole blood pressure after being given rosela tea was $139.67 \mathrm{mmhg}$

Table 4 Diastolic Blood Pressure after treatment

\begin{tabular}{llll} 
& Mean & $\mathrm{N}$ & $\begin{array}{l}\text { Std. } \\
\text { Deviasi }\end{array}$ \\
Dyastole & 87.33 & 30 & 5.208 \\
\hline
\end{tabular}

Table 4 shows that the mean (mean) of diastolic blood pressure after being given rosela tea is $87.33 \mathrm{mmhg}$ 


\section{STRADA Jurnal Ilmiah Kesehatan}

DOI: $10.30994 /$ sjik.v9i1.277

ISSN: 2252-3847 (print); 2614-350X (online)

Vol.9 No.1. May 2020. Page.162-169

c. Analysis

Table 5 paired t test results on systole and dyastole blood pressure

\begin{tabular}{lcccc}
\hline Variable & $\mathrm{N}$ & $\begin{array}{c}\text { Nilai } \\
\mathrm{p}\end{array}$ & $\alpha$ & conclusion \\
\hline Sistole & \multirow{2}{*}{30} & 0,000 & 0,05 & $\begin{array}{c}\mathrm{H}_{0} \\
\text { rejected }\end{array}$ \\
\cline { 3 - 5 } & & 0,001 & 0,05 & $\begin{array}{c}\mathrm{H}_{0} \\
\text { rejected }\end{array}$ \\
\hline
\end{tabular}

The results of the statistical analysis obtained $\mathrm{p}$ values for cystole pressure 0,000 and dyastole 0,001 , with alpha 0,05 , Ho was rejected, meaning roselle tea affected the decrease in blood pressure.

\section{DISCUSSION}

a. Systole blood pressure before being treated.

The results showed that the average value (mean) of Systole blood pressure before being given rosela tea was $145.33 \mathrm{mmHg}$ and dyastole was $91.33 \mathrm{mmHg}$

Hypertension is defined as a condition when blood pressure in a blood vessel increases chronically. This can happen because the heart works harder pumping blood to meet the body's oxygen and nutritional needs. If left unchecked, this disease can interfere with the functioning of other organs, especially vital organs such as the heart and kidneys (Ministry of Health, 2013). Explained in the results of basic health research (riskesdas) shows that the population with the work of farmers / fishermen / laborers has the highest prevalence of hypertension, namely $25 \%$ in non-infectious disease surveys.

Based on the facts of the observation and several theories above, the researchers argue that hypertension takes place chronically. Can not be detected without periodic checks and is influenced by habits that can reduce the diameter of the blood vessels both in the presence of cholesterol plaque and with blood vessel constriction.

If seen from the work of respondents who mostly work as farmers / fishermen / laborers with working hours starting from the morning until the afternoon, it can cause frequent dizziness, aches, and several other complaints that are considered normal. In addition, the habit among farmers and workers is rarely checked their blood pressure to health workers unless already in a severe condition. This can cause not to monitor blood pressure. High blood pressure can become chronic if not handled immediately, and cause the workload of the heart to increase which is described by high blood pressure over a long period of time.

b. Blood pressure after being treated

The results showed that the mean (mean) systole blood pressure after being given rosella tea was $139.67 \mathrm{mmHg}$ and diastole was $87.33 \mathrm{mmHg}$.

According to Khusnul Tri Ariyani, 2016 blood pressure can be reduced by consuming cosmetics such as rosella tea. The active role of organic compounds and antioxidants contained in the rosella flower itself is the content of gossiptin anthocyanins and hibiscin gluciside contained in it. As is known, rosella also contains a variety of important compounds, including a mixture of citric acid and malic acid, which produces a little fresh sour taste. The high content of ascorbic acid (vitamin C) and anthocyanin is 


\section{STRADA Jurnal Ilmiah Kesehatan}

DOI: $10.30994 /$ sjik.v9i1.277

a source of natural antioxidants that are very effective in counteracting various free radicals that cause cancer and various other diseases (Mardiah et al. 2009).

Based on the facts of the observations and some of the theories above, the researchers argue that the consumption of roselle tea is high with a decrease in the average blood pressure of systole and diastole. From the results of observations, 26 respondents did not take antihypertensive drugs. Researchers found 4 respondents who took antihypertensive drugs, namely respondents with stage 2 hypertension. Respondents continued to take medication as usual and drink rosella tea. There was a decrease in 3 respondents but one respondent was still stagnant in stage 2 hypertension. Although the 4 respondents took medicine and also drank rosella tea there were no complaints that occurred related to contra indications of drug interactions with rosella tea. In the second observation there were several complaints from the respondents who had the most heartburn after drinking rosella tea. Then the researchers conducted further interviews, apparently the respondents drank rosella tea before eating. This happens because stomach acid increases. Which is most likely due to the content of citric acid, malic acid, and high doses of vitamin $\mathrm{C}$. So that the researchers provided education to the respondents regarding the procedure for drinking rosella tea according to the procedure, then in the third observation no complaints were found by the respondents.

c. Effect of Rosella Tea Giving on Decreasing Blood Pressure

The results of studies before and after administration of rosella for 7 days found a significant decrease in mean (mean). Sistole pressure from 145.33 to 139.67 and diastole pressure from 91.33 to 87.33 . The results of the statistical analysis obtained $p$ values for cystole pressure 0,000 and diastole 0,001, with alpha 0,05, Ho was rejected, meaning roselle tea affected the decrease in blood pressure.

Today many people try to use alternative medicine using herbal plants, because besides being considered safer compared to synthetic drugs, the costs required are much lower. One of the medicinal plants suspected of being antihypertensive which began to be popularly used by Indonesian people as traditional medicine was rosella tea (Hibiscus sabdariffa linn). In lowering blood pressure rosella tea has advantages such as cheap, easy to obtain, and can help stabilize blood pressure with the right dose. Apart from a few advantages over rosella tea also has many disadvantages. Among them, the $\mathrm{pH}$ of drinks that tend to be acidic must be taken after meals to avoid increasing stomach acid. Besides rosella tea should not be consumed by someone who has blood pressure below normal because it can cause hypotension. There are also factors that can affect hypertension, one of which is age. The older a person's age, the higher his blood pressure. As we get older, almost everyone experiences an increase in blood pressure: systolic pressure continues to increase until the age of 80 years and diastolic pressure continues to increase until the age of 55-60 years. When a person's age increases, blood pressure will increase (Martuti, A, 2009). Along with increasing age, there is a decrease in organ function and organ system called degenerative. Starting from the ineffectiveness of fat metabolism becomes an impact on blood vessel stiffness due to plaque caused by bad fats. Increased blood concentrations that can result in increased heart work. And not to mention vasoconstriction that increasingly appears with age.

According to Indah SY and Slamet K (2012), the benefits of rosella for patients with hypertension can accelerate blood circulation by reducing the degree of blood viscosity, this occurs due to organic acids, polysaccharidesbelonging and antioxidantsto 


\section{STRADA Jurnal Ilmiah Kesehatan}

DOI: $10.30994 /$ sjik.v9i1.277

the flavonoidscontained in rosella petals as pharmacology. In addition, rosella also contains high levels of vitamin $\mathrm{C}$ which is useful for increasing the body's resistance to disease. Theantioxidants flavonoid in rosella tea are anthocyanins. In reducing blood pressure Anthocyanins prevent the formation of atherosclerosis, namely blockage and stiffness of blood vessels. Anthocyanin works to inhibit the process of arterogenesis by oxidizing bad fats in the body, namely Low Dencity Lipoprotein (LDL). Then Anthocyanins also protect the integrity of cells endothelialby coating blood vessels so thatcell damage does not occur endothelial which is the beginning of information atherosclerotic.

As a vasodilator working mechanism Anthocyaninsplay a role in smooth muscle. By relaxing blood vessels through activation of the Endothelium Derived Relaxing Factor (EDRF) so that vasodilators occur.

By consuming rosela tea 3 gr every $2 \mathrm{x}$ a day for 1 week a person is able to avoid stiffness in blood vessels, thin the blood flow and make blood vessels dilate. These factors can be used to reduce blood pressure. In addition, someone who has normal blood pressure can consume rosella tea to prevent hypertension.

Based on the results of the research and theory above, researchers argue that rosella tea can be an alternative solution in reducing pressure through antioxidant compounds that can prevent blood vessel stiffness. Soluble acid which acts as a decrease in blood viscosity. While the compound adiponectin acts as a vasodilator. It should also be noted that consumption of rosella tea has several advantages and disadvantages. Rosella tea not only functions as an medicine but also as a prevention of hypertension.

The results of this study are also supported by previous research Khusnul Ariyani, Sutanta 2016 in the midwifery journal vol. VIII. That there is an influence of giving Rosella tea to changes in blood pressure in patients with hypertension. Of the 20 respondents who were treated for 12 days 17 of them experienced a decrease in blood pressure.

There is one more study that is in line, namely by Yusni Syahrul (2012) in the Indonesian Cardiology Journal explaining that rosella tea can reduce blood pressure with an average decrease in systole $24.28 \mathrm{mmHg}$, diastole $8.57 \mathrm{mmHg}$ with consumption of 2 gr rosella $2 \mathrm{x}$ a day for 4 Sunday.

Viewed from the journals above, in this study there are several limitations. First from the time of the lack of research, both the number of respondents required extra observation, there was no comparison group in comparing the presence or absence of differences, and in terms of the dose the researchers used the dosage range of the existing journals, namely $2-5 \mathrm{gr}$. Which in this case the researchers only guessed and did not dare to take higher doses related to the side effects caused by rosella tea.

Based on the results obtained in the observations pre-test and post-test there was a decrease in the average blood pressure of systole and diastole. And the increase in standard deviation which shows the wider the range of variations in data from the average value, this can be interpreted that there is a decrease in blood pressure.

Supported by the two research journals above which mentioned a decrease in blood pressure in respondents after treatment, the researchers could conclude that rosella tea was effective in reducing blood pressure significantly in the community of Blimbing Rejotangan Tulungagung Village so that this can be used as an alternative choice for the management of pharmacological hypertension, based on limitations in the study, the researchers suggest the need for further research regarding the effective dose of rosella 


\section{STRADA Jurnal Ilmiah Kesehatan}

DOI: $10.30994 /$ sjik.v9i1.277

ISSN: 2252-3847 (print); 2614-350X (online)

Vol.9 No.1. May 2020. Page.162-169

tea in reducing blood pressure, the effective dose in grams per $\mathrm{kg}$ of body weight $(\mathrm{g} /$ kgbb).

\section{CONCLUSION}

Blood pressure systole before treatment is obtained an average of 145.33 and the average diastolic blood pressure is 91.33 .

Systole blood pressure after treatment was obtained with an average (mean) of 139.67 and the average diastolic blood pressure was 87.33.

There is a decrease in the average value of systole and diastole blood pressure after treatment, so rosella tea is effective against the reduction of blood pressure in hypertensive patients in Blimbing Rejotangan Village Tulungagung

\section{REFERENCES}

Ananta. (2009) Waspada Gejala Penyakit Mematikan. Nyutran ; Tugu Publisher

Andika, I Kadek Agus, Rompas Sefti, Mulyadi.(2014) . Pengaruh Pemberian Bunga Rosella

Terhadap Perubahan Tekanan Darah Penderita Hipertensi degan Terapi Captopril

- Didesa Kamiwangi Kecamatan Toili Barat Kabupaten Luwuk Banggai. Skripsi ;Universitas Samratulangi Manado.

Aryani, Tri kusnul, Sutanta. (2016). Pengaruh Pemberian Minum Teh Bunga Rosella Terhadap Perubahan Tekanan Darah Pada Penderita Hipertensi.Yogyakarta: Jurnal Kebidanan Vol. VIII No. 2. Diakses Dari www.journal.stikeseub.ac.id. Diakses pada tanggal 21 Nopember 2017 Pukul 19.02 WIB

Dinkes Tulungagung. (2014). Profil Kesehatan tahun 2014. Tulungagung: UPTD PSIK Kab. Tulungagung (2015). Profil Kesehatan tahun 2015. Tulungagung: UPTD PSIK Kab. Tulungagung

Hidayad. (2014 ). JNC VIII. Bersumber dari https://id.scribd.com/doc/244843425/JNC-VIII di akses pada 3 Januari 2018 pukul 16.00 WIB

Hidayat, A. Aziz. (2009). Metode Penelitian Keperawatan dan Teknik Analisa Data. Jakarta : Salemba Medika.

Murniati Anis, S.Kep, Ners, M. Biomed Dkk.(2016). Modul Praktikum Ilmu Dasar Keperawatan I..Tulungagung ; Madani Press

Notoadmojo, Soekidjo. (2008). Metodologi Penelitian Kesehatan. Jakarta : PT Rineka Cipta.

Nurarif, Amin Huda \& Kusuma, Hardhi. (2016) Asuha Keperawatan Praktisberdasarkan penerapan diagnosa Nanda, NIC, NOC dalam berbagai kasus. Jogjakarta : Mediaction

Nursalam, (2008), Metodologi Penelitian Ilmu Keperawatan. Jakarta : Salemba Medika.

Palmer, A.(2007). Simple Guide Tekanan Darah Tinggi. Erlangga ; Jakarta

Kemenkes RI. (2013). Riset Kesehatan Dasar Republik Indonesia 2013. Jakarta; Balitbangkes Kemenkes RI

Susilo, Wilhelminus Hary Dkk. ( 2014 ). Biostatistika Lanjut dan Aplikasi Riset. Jakarta ; Trans Info Merdia

Rahmawati, Reni. (2012). Budidaya Rosella Strategi “Memanen” Uang Dalam 4 bulan. Jogjakarta ; Pustaka baru press 


\section{STRADA Jurnal Ilmiah Kesehatan}

DOI: $10.30994 /$ sjik.v9i1.277

ISSN: 2252-3847 (print); 2614-350X (online)

Vol.9 No.1. May 2020. Page.162-169

Rajanh, Rajesh DR. (2016). JNC VIII Guide Lines. Sumber http://slideplayer.com/slide/5306680/. Diakses pada tanggal 16 januari 2018 pukul 23.15 WIB

Wikipedia. (2017). Tekanan Darah Tinggi, Bersumber dari: (https://id.wikipedia.org/wiki/Tekanan_darah_tinggi) di akses pada Tanggal 2 Januari 2018 pukul 13.45 WIB

Yusni, Syahrul. (2012). Kajian Kemampuan Rosella (Hisbiscus Sabdariffa) Dalam Menghambat Peningkatan Tekanan Darah Melalui Vasodilator Nitrit Oksida Pada Wanita Lanjut Usia Penderita Hipertensi. Banda Aceh: Jurnal Kardiologi Indonesia Vol 33, No. 3 diakses pada tanggal 21 Desember 2017 Pukul 21.15 WIB 